\title{
PEDAGOGIAS DO VENTO
}

\author{
ANDRÉ BRASIL \\ CÉSAR GUIMARÃES \\ PEDRO ASPAHAN
}

\begin{abstract}
RESUMO
0 artigo discute os processos de feitura do filme Nas giras do vento, criado no âmbito da Formação Transversal em Saberes Tradicionais da UFMG, de modo compartilhado com a mestra Maria Luiza Marcelino, que ministrou, em 2017, a disciplina "Confluências quilombolas contra a colonização". Trata-se de enfatizar o deslocamento do cinema para um contexto pedagógico, no qual 0 aprendizado de alunos, alunas e professores da universidade se encontra com a experiência de elaboração da história a partir da cosmologia afro-brasileira ligada à Umbanda, em um quilombo em Ubá, Minas Gerais. 0 artigo descreve os processos (nada lineares) que tornam o filme uma experiência multifacetada: sua inscrição nas imagens deixa traços de um trabalho que vem de longe, que 0 vento anuncia, transporta, transtorna, ensina e prossegue.
\end{abstract}

\section{PALAVRAS-CHAVE}

Cinema documentário; Saberes tradicionais; Quilombos; Umbanda.

\section{PEDAGOGIES OF THE WIND}

\begin{abstract}
The article discusses the filmmaking processes of the documentary Nas giras do vento (In the wind whirls), made in partnership with the traditional master Maria Luiza Marcelino, in the Program of Transversal Training in Traditional Knowledges of UFMG. The master was an invited lecturer in the course "Quilombola confluences against colonization" (2017). We discuss the process of making a documentary in an educational/pedagogical environment, specifically in a quilombo at the city of Ubá, Minas Gerais. We attempt to articulate this experience with the experience of elaborating history from an Afro-Brazilian perspective (specially related to Umbanda) and with learning processes in documentary filmmaking with students. The article thus describes the processes that make the film a multifaceted experience. Its inscription in images leaves traces of a work that comes from far away, something that the wind announces, transports, disrupts, teaches and keeps blowing.
\end{abstract}

\section{KEYWORDS \\ Documentary cinema; Traditional knowledges; Quilombos; Umbanda.}

\section{PÉDAGOGIES DU VENT}

\section{RÉSUMÉ}

L'article aborde les processus de réalisation du film Nas giras do vento, réalisé dans le cadre de la Formation Transversale aux Savoirs Traditionnels à l'UFMG, d'une manière partagée avec la maître Maria Luiza Marcelino, qui a enseigné, en 2017, la discipline "Confluences quilombolas contre la colonisation". Il s'agit de mettre l'accent sur le déplacement du cinéma vers un contexte pédagogique, dans lequel l'apprentissage des étudiants et professeurs de l'université rencontre l'expérience d'élaboration de l'histoire de la cosmologie afrobrésilienne liée à l'Umbanda, dans un quilombo en Ubá, Minas Gerais. L'article décrit les processus (non linéaires) qui font du film une expérience aux multiples facettes: son inscription dans les images laisse les traces d'une œuvre qui vient de loin, que le vent annonce, transporte, bouleverse, enseigne et continue.

MOTS-CLÉS 
Cinéma documentaire; Connaissances traditionnelles; Quilombos; Umbanda.

\section{PEDAGOGÍAS DEL VIENTO}

\section{RESUMEN}

El artículo discute los procesos de realización de la película Nas giras do vento, creada dentro del ámbito de la Formación Transversal en Conocimientos Tradicionales en UFMG, de manera compartida con la maestra Maria Luiza Marcelino, quien enseñó, en 2017, la disciplina "Confluencias quilombolas contra la colonización". Se trata de enfatizar el desplazamiento del cine a un contexto pedagógico, en el que el aprendizaje de estudiantes y profesores en la universidad se encuentra con la experiencia de elaborar la historia de la cosmología afrobrasileña vinculada a Umbanda, en un quilombo en Ubá, Minas Gerais. El artículo describe los procesos (no lineales) que hacen de la película una experiencia multifacética: su inscripción en las imágenes deja huellas de un trabajo que viene de lejos, que el viento anuncia, transporta, altera, enseña y continúa.

\section{PALABRAS CLAVE}

Cine documental; Conocimiento tradicional; Quilombos; Umbanda. 


\section{OS MUITOS ENCONTROS COM OS MESTRES DOS SABERES TRADICIONAIS NA UNIVERSIDADE}

Desde 2014 a UFMG recebeu em torno de sessenta mestres e mestras das culturas afro-brasileiras, indígenas e populares, que ofereceram cursos abertos aos alunos de todas as graduações e pós-graduações. Inicialmente apoiados pelo INCT de Inclusão no Ensino Superior e na Pesquisa, os mestres foram acolhidos, em seguida, pelo Programa de Formação Transversal em Saberes Tradicionais, sustentado desde então pela Pró-Reitoria de Graduação . Eles nos ofereceram um variadíssimo leque de conhecimentos: os cuidados com a saúde nas comunidades quilombolas e indígenas, a partir das plantas medicinais e do cultivo agroecológico; a cosmociência dos Guarani e Kaiowá, Mbya-Guarani, Maxakali, Xavante, HuniKuin e Tupinambá; as formas de vida e de pensamento nas comunidades do Rosário e nos terreiros de Candomblé e Umbanda; o cinema Maxakali e Xavante; a cerâmica, a culinária e a construção Xacriabá; a construção Maxakali; a arte das miçangas entre os Krahô, Huni-Kuin e Maxakali; a construção de caixas, tambores e pifes no contexto das danças e cantos populares; os saberes sobre a terra e a imaginação política dos povos Tupinambá, dos quilombos urbanos, dos assentamentos agroecológicos e dos terreiros².

Desde a sua criação, o Programa produziu um variado material audiovisual, com o intuito de oferecer subsídios para o ensino da história e da cultura afro-brasileira e dos povos indígenas, disponibilizado em nosso site (www.saberestradicionais.org). Esse material é um documento vivo das formas de pensamento não-eurocêntricas que contribuem para a instauração de práticas de ensino e de pesquisa verdadeiramente contra-colonizadoras na universidade, segundo a formulação do mestre quilombola Antônio Bispo dos Santos (SANTOS, 2015, p. 47-48). Ao longo do trabalho de registro dos cursos, chegamos a três formatos principais: as videoaulas, os retratos audiovisuais e os filmes documentários. As videoaulas, de duração mais longa, acompanham ao máximo a continuidade da aula e trazem intertítulos que indicam os assuntos tratados, para orientar o espectador ${ }^{3}$. Os retratos, criados fora do ambiente de aula, dedicam ao mestre uma escuta que the permite narrar seu percurso de vida e contar como se deu o aprendizado do saber do qual hoje ele é o

\footnotetext{
${ }^{1}$ As Formações Transversais foram regulamentadas pelo Conselho de Ensino, Pesquisa e Extensão da UFMG pela Resolução 19/2014. José Jorge de Carvalho, coordenador do INCT - Instituto Nacional de Ciência e Tecnologia e Inclusão no Ensino Superior e na Pesquisa criou, pioneiramente, na UnB, o projeto Encontro de Saberes, que promove a interlocução entre o conhecimento acadêmico e os saberes dos mestres das comunidades tradicionais. (Cf. http://www.inctinclusao.com.br/encontro-de-saberes/encontro-de-saberes).

${ }^{2}$ A ementa dos cursos, a identificação dos mestras e os materiais audiovisuais estão reunidos no site www.saberestradicionais.org.

${ }^{3}$ Exemplos disponíveis em: https://www.saberestradicionais.org/category/videoaulas/. Acesso em $17 / 07 / 2020$.
} 
portador ${ }^{4}$. Já os documentários, feitos de diferentes registros, conjugam o depoimento dos mestres às performances e construções partilhadas da mise-en-scène documentária.

Рara os efeitos desse artigo, descreveremos o encontro que se originou de uma experiência de aprendizagem no âmbito do cinema documentário, quando alunos e professores se encontraram com Maria Luiza Marcelino, liderança quilombola da Associação Namastê e zeladora do Centro Espírita Caboclo Pena Branca, em Ubá, Minas Gerais. Já havíamos realizado uma experiência similar, quando filmamos e montamos coletivamente o filme O boi de Oliveira (2018), por ocasião da festa de Nossa Senhora do Rosário, na cidade de Oliveira, em setembro de 2017. Nessa ocasião, fomos convidados por Pedrina Lourdes dos Santos, capitã da Guarda de Massambique Nossa Senhora das Mercês, e uma das mestras no curso Catar folhas: saberes e fazeres do povo de axé, oferecido naquele ano ${ }^{5}$. O encontro propriamente fílmico - com a mestra Maria Luiza Marcelino revestiu-se, porém, de um caráter de acontecimento, como mostraremos a seguir.

Nosso primeiro encontro com Maria Luiza se deu por acaso, numa tarde, na cantina da Faculdade de Filosofia de Ciências Humanas da UFMG, em 2017. Ela estava em companhia de Moema de Souza Carneiro, gestora do Museu Ginásio São José, de Ubá, e de Sônia Queiroz, professora da Faculdade de Letras. Iniciada a conversa, Maria Luiza não demorou para nos mostrar o seu livro, Quilombola: lamento de um povo negro (custeado com o seu trabalho de doceira). Pouco tempo depois, tomados pela força do seu relato, nós a convidamos para assumir um dos módulos do curso "Confluências quilombolas contra a colonização", na sequência das aulas dadas pelos mestres quilombolas Antônio Bispo dos Santos (Saco Curtume, Piauî) e Arnaldo de Lima (Custaneiras, Piauí).

Logo na primeira aula, ela nos surpreendeu ao expor como compreendia o encontro que ali ocorria, no Jardim Mandala, na Faculdade de Educação. Incumbida pelas entidades espirituais de levar adiante a luta dos quilombolas que a precederam, ela afirma que nós professores e alunos - estávamos sendo "engolidos" por uma força que nos arrastava 6 . As entidades - em especial o caboclo Marunguinho - nos convocavam para "ressuscitar a terra, que está morrendo". Mas esse possível encontro entre os nossos "projetos" e o trabalho espiritual que ela faz, ao nos "puxar" para a luta deles - não se faz sem levar em conta o que

\footnotetext{
${ }^{4}$ Exemplos disponíveis em: https://www.saberestradicionais.org/category/video-retratos/ Acesso em 17/07/2020.

${ }^{5}$ O registro da festa se deu no Laboratório de documentário (ministrado pelos professores André Brasil, César Guimarães e Eduardo Rosse) e a montagem, na Oficina de montagem (ministrada pelos professores César Guimarães, Eduardo de Jesus e Pedro Aspahan). O filme está disponível em: https://youtu.be/dacsdF3GvMM. Acesso em 17/07/2020.
}

\footnotetext{
${ }^{6}$ Aula disponível em https://www.saberestradicionais.org/filmes/.
} 
também nos separa: "vocês, que acabaram com nós, vocês têm que nos ressuscitar" (é o que os espíritos pensam na cabeça deles, ela ressalta) ${ }^{7}$. Quem nos atraíra para esse encontro foram os "negros sábios", os espíritos daqueles que foram maltratados e encurralados. Eles guiavam nossa conversa naquela tarde. Aqueles que um dia foram escravizados e perseguidos "querem voltar, estão voltando", e nós somos instrumentos para essa volta que - somente ela - pode trazer a vida de volta à terra. Eles, que foram mortos violentamente, não querem que a terra morra também, ela enfatiza. Nós, da universidade, estamos "entrando de cabeça" nessa relação, mas sem saber do que se trata. Os caboclos e os pretos velhos - dos quais Maria Luiza é a porta-voz - levam-nos a lugares que sequer imaginávamos: "se não vem pelo amor, vem pela dor", ela disse, calma e severamente. Foi essa "corrente" que se formara ali, naquela aula - puxada por Maria Luiza, por sua vez puxada pelos espíritos, que nos levou, dois anos depois, ao Centro Espírita Caboclo Pena Branca, para fazermos um filme. Ou, pelo menos, era assim que definíamos, do nosso modo, o novo encontro que buscávamos. A seguir, mostraremos como isso se deu.

\section{A CRIAÇÃO VISUAL PARTILHADA}

Desde o início, procuramos documentar os saberes que os mestres nos traziam, antevendo que o registro audiovisual contribuiria em muito para a redação dos memoriais necessários para a concessão do título de Notório Saber, tarefa na qual já se engajava, à época, um grupo de professores parceiros ${ }^{8}$. 0 trabalho com o audiovisual também tem uma função pedagógica, pois os processos são feitos tanto com o apoio dos bolsistas de graduação e pós-graduação, quanto por meio de disciplinas de realização e de montagem configuradas para acompanhar as aulas dos mestres. A criação audiovisual é duplamente partilhada: feita em parceria com os mestres - que têm, cada um à sua maneira, uma marcante consciência de se saberem filmados, apresentando temas, proposições formais e sugestões de mise-en-scène nas situações a serem filmadas -, e no aprendizado coletivo adquirido pelos alunos diante das questões éticas, técnicas, estéticas e políticas próprias do documentário.

Dando prosseguimento à feitura dos vídeo-retratos, que incluía também naquele semestre os retratos de Pai Ricardo de Moura (zelador da Casa de Caridade Pai Jacob do Oriente, de Belo Horizonte) $)^{9}$ e de Pedrina Lourdes dos Santos (capitã do Massambique de

\footnotetext{
${ }^{7}$ Preferimos manter o registro oral de Maria Luiza Marcelino, para garantir a força de sua fala, já que ela se reporta ao ponto de vista das entidades espirituais.

8 Cf. a resolução, aprovada em 25 de maio de 2020: https://ufmg.br/comunicacao/publicacoes/boletim/edicao/2091. Acesso em 17/07/2020.

9 Disponivel em: https://www.saberestradicionais.org/retrato-do-mestre-pai-ricardo-de-moura/ Acesso em 19/03/2021.
} 
Nossa Senhora das Mercês, de Oliveira) ${ }^{10}$, chegamos à casa de Maria Luiza Marcelino, em Ubá, junto com os alunos do Laboratório de Realização Documental: Saberes Tradicionais. Desta vez, em especial, o trabalho de filmagem resultou do processo formativo dos próprios alunos, pois muitos deles não tinham nenhuma experiência anterior no campo do audiovisual. Para nós, essa foi uma oportunidade de sistematizar nossa relação com os sujeitos filmados, a partir de alguns critérios: a escuta detida e atenta da fala e dos cantos; a construção conjunta da mise-en-scène; a adoção do plano fixo, do plano-sequência e da montagem que valoriza a continuidade, a longa duração dos planos e a relação com o fora de campo (em diálogo com as questões cosmológicas e espirituais trazidas pelos mestres); além de contar com o método de criação coletiva, que inclui o aprendizado e a formação dos alunos no processo mesmo de realização do filme.

O que resulta da experiência cinematográfica é sempre uma conjunção de fatores técnicos, estéticos e políticos muito complexos, pois o cinema é uma forma que pensa, como bem definiu Godard ${ }^{11}$. O amadurecimento do aprendizado por meio da experiência fílmica leva tempo e envolve vários aspectos: as conjunções entre o olhar/escutar/perceber (a experiência fílmica) e o trabalho das mãos (a realização), que nos permitem notar as nuances e as sutis diferenças entre um plano e outro; como manter o plano fixo e suportar a tentação da resposta imediata a um estímulo que vem do fora de campo, no calor da filmagem; como sustentar o silêncio que se instaura após uma fala perturbadora, na densidade temporal oferecida pela oralidade própria do mestre; como escutar com calma o que ele tem a nos dizer, sem nos preocuparmos com a próxima pergunta, saindo da lógica da entrevista e nos aproximando da conversa e da partilha; como assumir o rigor da escolha em filmar com apenas uma câmera (e não com dezenas delas, como é comum na estética televisiva). Essas são algumas das questões que discutimos exaustivamente com os alunos antes de iniciarmos as filmagens, e que os deixavam atônitos, tão habituados estavam eles com a padronização das abordagens próprias à estética televisiva, ao jornalismo e à internet, em geral, alheias à singularidade do outro que é filmado.

Além disso, tínhamos também uma questão ética delicada, pois ao filmarmos três mestres negros vinculados às religiões de matriz africana - da Umbanda e do Candomblé Angola - não queríamos repetir os erros de certa cinematografia brasileira documental que buscou explicar - segundo a lógica branca, colonizadora e ocidental - as experiências espirituais de comunidades religiosas tradicionais muito distantes e diferentes da realidade do cineasta, e acabou produzindo imagens exotizantes de incorporações e rituais sagrados,

\footnotetext{
${ }^{10}$ Em edição.

11 “O cinema é uma forma que pensa" : fórmula recorrente em História(s) do Cinema (1988-1998).
} 
muitos deles, inclusive, interditados à filmagem (o que trouxe consequências desastrosas). Em "Filmar os terreiros, ontem e hoje", César Guimarães destaca a reivindicação atual dos mestres, que recusam o lugar de "objetos" de pesquisa que thes foi atribuído por tanto tempo e assumem o protagonismo de suas histórias, ao participarem ativamente dos processos de criação fílmica. Segundo o autor, o trabalho de mediação do cineasta

"vê-se hoje fortemente desestabilizado por três fatores: as reivindicações em torno da auto-representação por parte daqueles que foram sistematicamente silenciados ao longo da história; a denúncia do lugar de fala pretensamente universal assumido pelos sujeitos brancos; a desconstrução crítica do que Grada Kilomba chamou de 'o traumatizante contato com a violenta barbaridade do mundo branco'" (GUIMARÃES, 2019, p. 26).

Como construir então uma parceria fílmica com os mestres, de forma a respeitar a cosmovisão que os anima e a alteridade do seu mundo, e ainda conjugá-la a uma situação de aprendizado na qual nossos alunos se iniciavam? Essa inquietação nos levou a buscar formas partilhadas de construção fílmica, sem perder de vista a dissimetria entre quem filma e quem é filmado, mas também sem deixar de almejar que a reciprocidade viesse, generosamente, alcançar nossa relação com aqueles a quem queríamos filmar. Uma das primeiras decisões que tomamos, entre nós, é que não filmaríamos nem a incorporação nem os rituais sagrados. Foi assim que partimos em um ônibus da universidade - cerca de trinta pessoas (professores, alunos e estagiários) - para filmar o vídeo-retrato de Maria Luiza Marcelino, em Ubá, zona da mata mineira.

\section{ESCREVER - COM A CÂMERA - NO CADERNO DE CAMPO}

Já era noite quando chegamos ao terreiro. Lá, Maria Luiza nos esperava para dar início à sessão. Os médiuns estavam concentrados no pequeno salão, junto com os ogãs. Ela não se apressou, e fez questão de nos receber em sua casa com café, biscoito frito, bolo de fubá, cachorro quente, laranjada e suco de goiaba (tudo caseiro, feito por ela). No salão, nos apertamos no espaço reservado para a assistência. O congá estava repleto de imagens de pretos velhos e caboclos. Uma grande estátua de Oxalá (sincretizado com Cristo) mantinha os braços erguidos sobre nós, diante de um quadro de lemanjá. Em outro canto, um caboclo empunhava seu arco e flecha. A sessão começa; os caboclos são os primeiros a chegar, com seus gestos e sons peculiares. O grupo de médiuns é pequeno, formado em sua maioria por mulheres. Do lado esquerdo, os três atabaques eram tocados pelo irmão mais velho da mestra, por uma criança (seu neto), e por outra mulher que se revezava com outra criança. Em seguida, chegaram os pretos velhos e a assistência recebeu o passe de todos eles, um por um, demoradamente (mas apenas a preta velha de Maria Luiza falava e dava seus conselhos). Quase meia noite, pensamos que a sessão chegara ao fim. Fez-se um breve intervalo e se iniciou uma segunda e fortíssima sessão, dedicada aos exus e às pombagiras. As velas foram 
quase todas apagadas, e o congá, velado por uma cortina. No centro, um caldeirão ostentava o fogo alimentado pela cachaça, que, incandescente, era levada à boca. A liberadora energia desencadeada pelos exus, desafiadores, e pelas pombagiras, provocadoras, era tremenda, de enorme intensidade. Quando a sessão terminou, ficamos a pensar no que o dia seguinte nos reservaria.

Em Ubá, toda a turma se hospedou na Escola Estadual Governador Valadares (vinculada à comunidade quilombola), junto da qual Maria Luiza tem intensa atuação. Na manhã seguinte à sessão, fomos ao encontro dela para gravar seu retrato. Tivemos a sorte e a honra de ter em nossa turma, cursando a disciplina, Isabel Casimira Gasparino (Belinha), Rainha da Guarda de Congo e Moçambique Treze de Maio e Rainha Conga do Estado de Minas Gerais, além de realizadora ${ }^{12}$. Contamos também com a presença de Gabriel de Moura, filho de Pai Ricardo de Moura, importante liderança jovem dos movimentos negros e das religiões de matriz africana em Belo Horizonte. Ele atuou como um de nossos monitores no semestre anterior e fazia agora a disciplina de realização. Gabriel, juntamente com seu pai, preparou um presente para Maria Luiza. Ao iniciar o trabalho, construímos uma cena fílmica na qual Belinha e Gabriel viriam cantando e carregando o presente, como uma oferenda, até entrarem no terreiro e encontrarem com Maria Luiza. Toda a cena foi decupada de modo ficcional. Dentro do salão, deixamos tudo preparado para a conversa: a posição da câmera, a organização do espaço, a iluminação e o som, mas começamos a filmar do lado de fora, no quintal. Quando finalmente Belinha e Gabriel encontraram Maria Luiza, a cena saiu do controle. Ali, o acontecimento seguiu seu curso para além da ficcionalização, e tentamos correr atrás dele para não perder o fio da meada. Após os cumprimentos e as bênçãos, os três adentraram o salão, enquanto fazíamos o registro de fora. Não fazia sentido interromper o fluxo do acontecimento para refazer a cena; então nos colocamos como observadores, um pouco mais distanciados, e nos desdobramos tecnicamente para dar continuidade ao registro. As duas alunas que cuidavam do som ficaram um pouco atordoadas com a inesperada continuidade do acontecimento, como que paralisadas diante do não saber e do improviso que ele provocava. Corremos para dentro do salão sem interromper a gravação, ajustando rapidamente câmera, tripés, gravador, vara e microfones, corrigindo também o novo enquadramento e o novo posicionamento que tivemos de adotar no espaço. Era possível perceber, com essa experiência, como éramos nós que tínhamos que nos adequar e improvisar diante do acontecimento, e não o contrário.

Maria Luiza estava ainda se acostumando com seu lugar de auto-encenação diante da câmera, mas aos poucos ela se solta e inicia uma belíssima interpretação do presente que

\footnotetext{
${ }^{12}$ Belinha protagonizou e co-dirigiu, junto com Júnia Torres, o filme A Rainha Nzinga chegou (2019).
} 
The foi entregue, plena de simbolismos ${ }^{13}$. A moringa de barro representava a origem da vida e a resistência do povo negro, pois as mulheres a usavam, às escondidas, para dar água aos negros escravizados presos no tronco após a tortura. Fala ainda das cores do tecido que ela ganhara: o azul representava o céu; o branco, a água; o escuro, a vivência. A palha servia para acobertar os corpos dos adultos e das crianças; as flores, as sempre-vivas, enfeitavam as festas e rituais; a vela remontava ao tempo dos candeeiros feitos do sebo dos bichos. Ao destacar a importância da terra, pois tudo vem dela - a vida e a cura das doenças, o alimento do corpo e do espírito, e a própria sobrevivência de seu povo - Maria Luiza nos alerta:

Vocês estão aqui, acham que é por acaso? Não é. Por quê? Esse é um trabalho que vocês estão fazendo, não é tanto porque vocês querem, mas "Eles" querem que vocês peguem as pessoas que podem ter o conhecimento para levar isso para as outras gerações. Pois muitos serão contra, mas também muitos serão a favor da nova medicina, da nova educação e dos novos gêneros. E saber também "quem sou eu? De onde eu venho?" Porque se você não sabe quem é você e de onde vem, nunca vai se encontrar. (...) Os jovens querem falar língua enrolada, falar que vieram de Portugal, de Paris, mas ninguém fala: "Eu vim da mata, eu vim do quilombo"14.

Diferentemente dos nossos primeiros encontros, quando ela se mostrava receosa diante dos protocolos acadêmicos, agora sua fala era mais direta e franca, carregada de uma doçura e de uma enorme abertura para narrar suas lutas e conquistas, e sua ligação com a ancestralidade. Com um vastíssimo conhecimento de pontos cantados, ela marcou sua trajetória de vida com alguns deles, comentando o seu significado. Certamente, o fato de termos ido todos juntos até o terreiro e participado da sessão de sexta-feira foi algo decisivo para as interações que se seguiram. Também do ponto de vista do aprendizado dos alunos, a experiência da sessão de Umbanda, nova para muitos deles, foi muito forte, marcante e definidora de um posicionamento ético e de uma compreensão mais abrangente do universo no qual estávamos adentrando, servindo de referência e guia para o filme em seu processo coletivo de realização.

Terminada a conversa, almoçamos e seguimos para uma visita às ruínas da antiga sede da Fazenda Liberdade, onde membros da família e da comunidade de Maria Luiza foram escravizados; muitos deles estavam ali enterrados. Ela organizou essa visita e fez questão de que filmássemos lá, em sua companhia. Sem saber muito bem como conduzir a filmagem, fomos, mais uma vez, guiados por ela. Logo que o ônibus chegou à fazenda, percebemos um clima muito carregado. Na noite anterior, após a sessão, um de nós sonhara que se desviava de um cavalo bravo para não levar um coice. Na primeira caminhada pela fazenda, passamos por um grupo de trabalhadores que brigavam entre si, xingavam e gritavam. Ela os chamou de "os novos capatazes". De repente, veio em nossa direção um cavalo que empinava e

\footnotetext{
${ }^{13}$ Essa sequência entrou apenas no retrato da mestra, ainda em finalização.

${ }^{14}$ Fragmento da fala de Maria Luiza retirado de seu retrato, ainda inédito.
} 
relinchava, montado em pêlo por um menino. Os novos capatazes são agressivos e violentos. Batem no menino e nos cavalos com chicote. Maria Luiza diz que a escravidão ali não acabara. A ideia inicial, proposta por ela, era filmarmos no espaço do cemitério dos escravizados, mas ега impossivel chegar até lá, por causa do tumulto dos cavalos e das discussões entre os "novos capatazes".

Como era difícil administrar uma situação tão tensa com uma turma de muitos alunos, resolvemos nos dividir em grupos. Nosso grupo seguiria filmando com Maria Luiza, enquanto outros grupos se formaram para filmar, de modo autônomo, na mata ao redor da sede. Eles deveriam acompanhar a Rainha Belinha (que saíra para catar folhas, como vimos na abertura do filme), gravar planos da paisagem e das crianças do quilombo passeando pelos arredores da fazenda. Assim, nosso grupo se afastou dos trabalhadores e posicionamos a câmera bem distante das ruínas da fazenda, que apareciam ao fundo. Maria Luiza inicia a sua gira no descampado à nossa frente. Combinamos apenas que ela andaria pelo espaço para que pudéssemos apresentar o lugar. Ela não só caminha calmamente, num longo plano sequência, como, vindo em nossa direção, solta seu canto: "Fazenda velha não tem mais trabalhador, aranha corta a cana, marimbondo é moedor." E logo depois, emenda: "Acabou, acabou o sonho dos quilombos. O sonho acabou, a terra acabou, mas nós estamos ainda vivos, que é o mais importante!" Ela fala que a memória resiste à sofrida destruição física da fazenda, às suas ruínas, pois tem algo que "eles nunca podem nos tirar, que é a liberdade na nossa cabeça, na nossa alma e no nosso corpo".

Maria Luiza inventa, de improviso, diante da situação de filmagem, um ritual formado por várias giras. Ela caminha sempre em círculos no descampado diante das ruínas da fazenda. Na primeira gira, com o canto, anuncia o fim da fazenda. Na segunda, invoca os pretos velhos: "Quem caminha com as almas, caminha devagarinho. É devagar, é devagarinho, quem caminha com as almas nunca se perde no caminho". Ela saúda Nossa Senhora do Rosário, as almas dos escravos, os ancestrais de seu povo. Saúda também Ogum, Oxalá, Xangô e Zumbi.

Numa terceira gira, chama seus netos e os apresenta: Narlon, Maycon e Flávia. Ergue sua netinha e diz que, assim como ela tinha sido escolhida, quando criança, Flávia fora escolhida pela comunidade e pelos Orixás para dar continuidade ao trabalho no terreiro. A criança, futura Mãe Pequena, foi gerada e feita por lansã. Maria Luiza faz uma roda, canta e dança com os meninos (que assumem, simbolicamente, o lugar dos Erês). Numa quarta e última gira, ela apresenta toda a família do terreiro no meio do descampado, canta uma canção de despedida, agradecendo, e resolve tirar uma foto bem em frente às ruínas do casarão da fazenda. As mulheres e as crianças caminham até lá, em mais um longo plano sequência. Estamos muito distantes e filmamos de bem longe. Maria Luiza ergue novamente sua netinha, filha de lansã, diante das ruínas da fazenda. Nesse exato instante, começa uma 
impressionante tempestade, com o vento quase dobrando os enormes coqueiros ao fundo da fazenda destruída. A tarde escurece e o dia vira noite, de repente. O vento forte levanta poeira, sacode as copas das árvores. Galhos e folhas saem voando. As crianças e as mulheres vêm correndo em busca de abrigo. Começa a relampejar. Tentamos nos manter firmes com a câmera, diante do acontecimento. Maria Luiza grita: "Corre gente, que lansã tá respondendo, lansã tá confirmando". Um dos alunos comenta que o microfone de lapela não está funcionando bem, como se estivesse estragado. Falo que é o vento. Maria Luiza reforça: "Sim, é o vento que fala e conduz as coisas".

Com medo da tempestade que se armava, nos abrigamos no ônibus. Ainda assim, paramos na estrada, recuados, para filmar o vento que varria a fazenda e lembramos que, dois dias antes da viagem, havíamos visto, com os alunos, o filme de Joris Ivens, A história do vento (1988). Seguimos para a escola. Ao chegar, corremos com a câmera. No exato instante em que entramos, o céu desaba numa intensa tempestade. Não tomamos um pingo de chuva sequer. Na escola, gravamos o canto final de Maria Luiza para lansã, tomados pela gratidão e ainda impactados pela impressionante experiência do dia. Ela havia nos avisado. Fomos a Ubá pensando em fazer um trabalho e acabamos participando de outro, fortemente conduzido pela mestra, na sua enorme capacidade de improviso e de criação em sua relação com a espiritualidade. Tivemos ainda a sorte de revisarmos as imagens que fizemos no dia, discutindo-as coletivamente no saguão da escola: alunos e professores com Maria Luiza e sua família, enquanto a chuva ainda caía do lado de fora, com a certeza de que tínhamos registrado ali um fortíssimo material.

\section{QUE FAZ 0 FILME GIRAR}

O processo de filmagem e construção de uma mise-em-scène compartilhada com Maria Luiza envolveu os alunos em um aprendizado não apenas técnico, mas de escuta, atenção e perspicácia para responder às situações imprevistas, para lidar com a emergência do acontecimento e acompanhar a mestra no ritual que criou na visita à Fazenda Liberdade. Trata-se de uma pedagogia que acontece em vários níveis e que precisa levar em conta a mediação da câmera e dos equipamentos de captação do som, a relação entre o enquadramento e os sujeitos filmados, o modo como somos desestabilizados pela imprevisibilidade e pela parcela de mistério dos eventos que o atravessam. Destacamos aqui o quanto esta peculiar aprendizagem da criação fílmica deve levar em conta uma diferença essencial entre os gêneros cinematográficos: se na ficção é o mundo que está no quadro (como universo representado no interior de suas bordas), "no documentário é o quadro que está no mundo" (NINEY, 2009, p. 70). Se o documentário é uma forma que se faz na sua relação com as forças do fora, que o atravessam e o configuram de dentro, o maior desafio 
está em dar consistência a essa escrita cinematográfica conformada pela relação com os sujeitos filmados e os elementos que vêm do seu mundo (interior e exterior). Este é também um momento de aprendizado de um cinema feito de modo compartilhado e que precisa, portanto, se abrir à auto mise en scène dos sujeitos filmados (COMOLLI, 2008). Essa pedagogia, elaborada junto aos alunos, acaba por se inscrever no filme para reverberar também na experiência do espectador. Afinal, o filme montado, guarda, em sua organização formal, as marcas dos processos de sua feitura e dos encontros com Maria Luiza. Vejamos então essa pedagogia que, estando pronto o filme, se endereça ao espectador, levando em conta o modo como a forma abriga os aprendizados de seu processo (alunos, professores, a mestra Maria Luiza e sujeitos incluídos). Concluiremos o artigo com uma breve abordagem do filme de maneira a ressaltar como a mise-en-scène compartilhada, a narrativa das giras e dos pontos cantados e a montagem que faz coabitar tempos diferentes, convoca o espectador a lidar com a experiência do quilombo em Ubá - traços de sua história e de sua cosmologia - não apenas sob o modo da transparência, mas da opacidade e da intensidade próprias aos acontecimentos que constituem as imagens e os sons.

Abre Nas giras do vento - nome escolhido para o documentário - um plano que se prolonga como enigma. Isabel Casimira percorre uma estrada, pés descalços, a carregar os ramos de espinheira santa. O corte para a cartela de abertura nos priva de prosseguir com ela, de modo a saber seu destino, e agora vemos a cidade de Ubá do alto de um morro: em uma mise-en-scène deliberadamente construída, Marlon adentra o enquadramento, olha firme para a câmera e entoa o ponto da Umbanda:

Oxóssi mora no pé da gameleira. Oxóssi mora no pé da gameleira.

Ogum mora na lua,

Pai Xangô lá na pedreira.

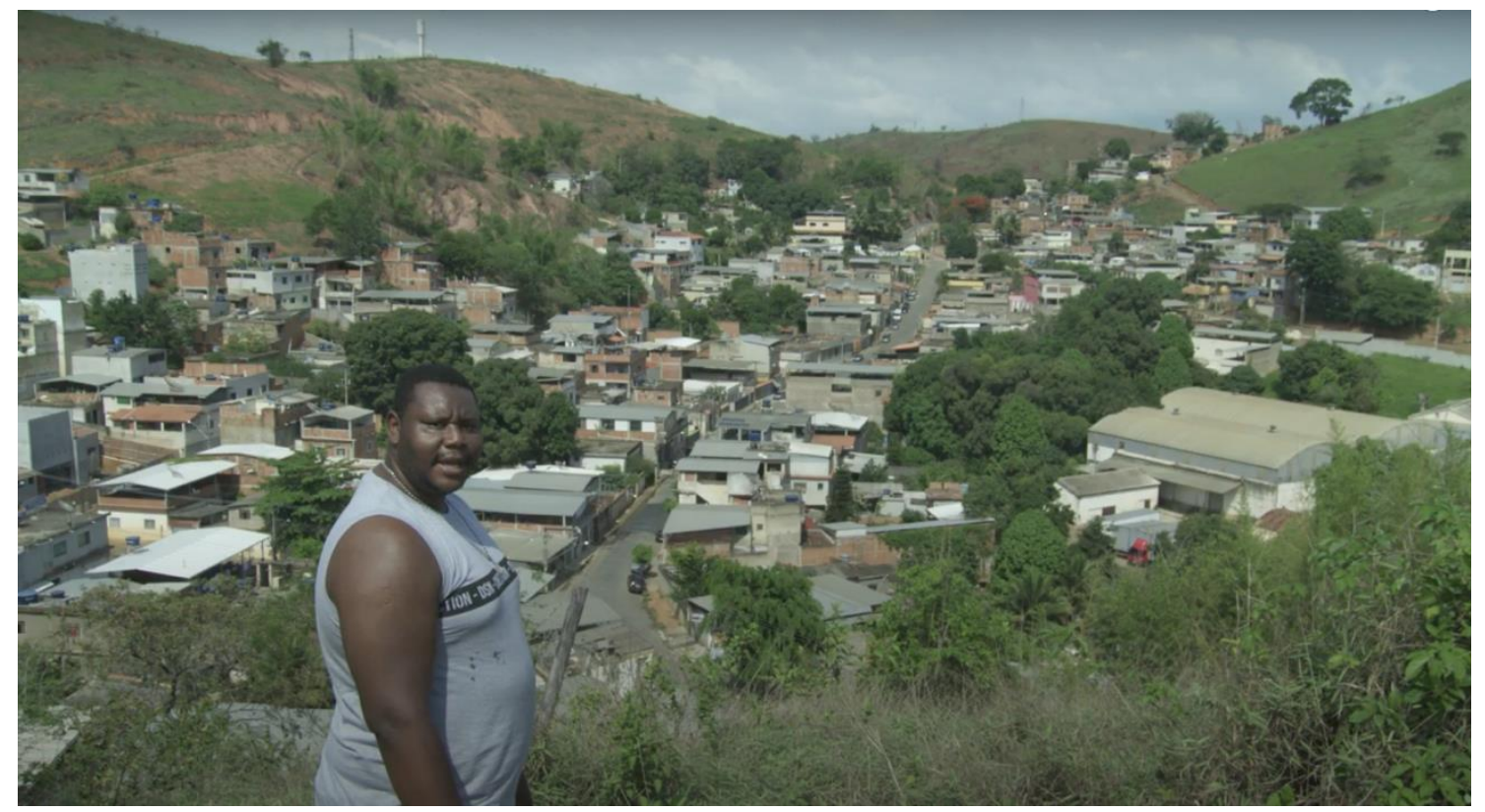


Ele sai do quadro e o plano permanece um pouco mais, para então nos apresentar o título do filme. Em sucessivos enquadramentos, as imagens vão então nos aproximando, como se adentrássemos o lugar do Centro Espírita Caboclo Pena Branca: primeiro um plano um pouco mais fechado da generosa mangueira, os sons dos bichos em torno. Em um corte, ouvimos os passos da criança que atravessa a imagem correndo, enquanto a avó, Maria Luiza, vestida de branco, olha a câmera, como a aguardar uma visita. Os planos tornam-se mais próximos, encontram o olhar de Maria Luiza e assim, dentro do barracão, vemos a legião de encantados - Orixás, caboclos e pretos velhos - a nos mirar do congá.

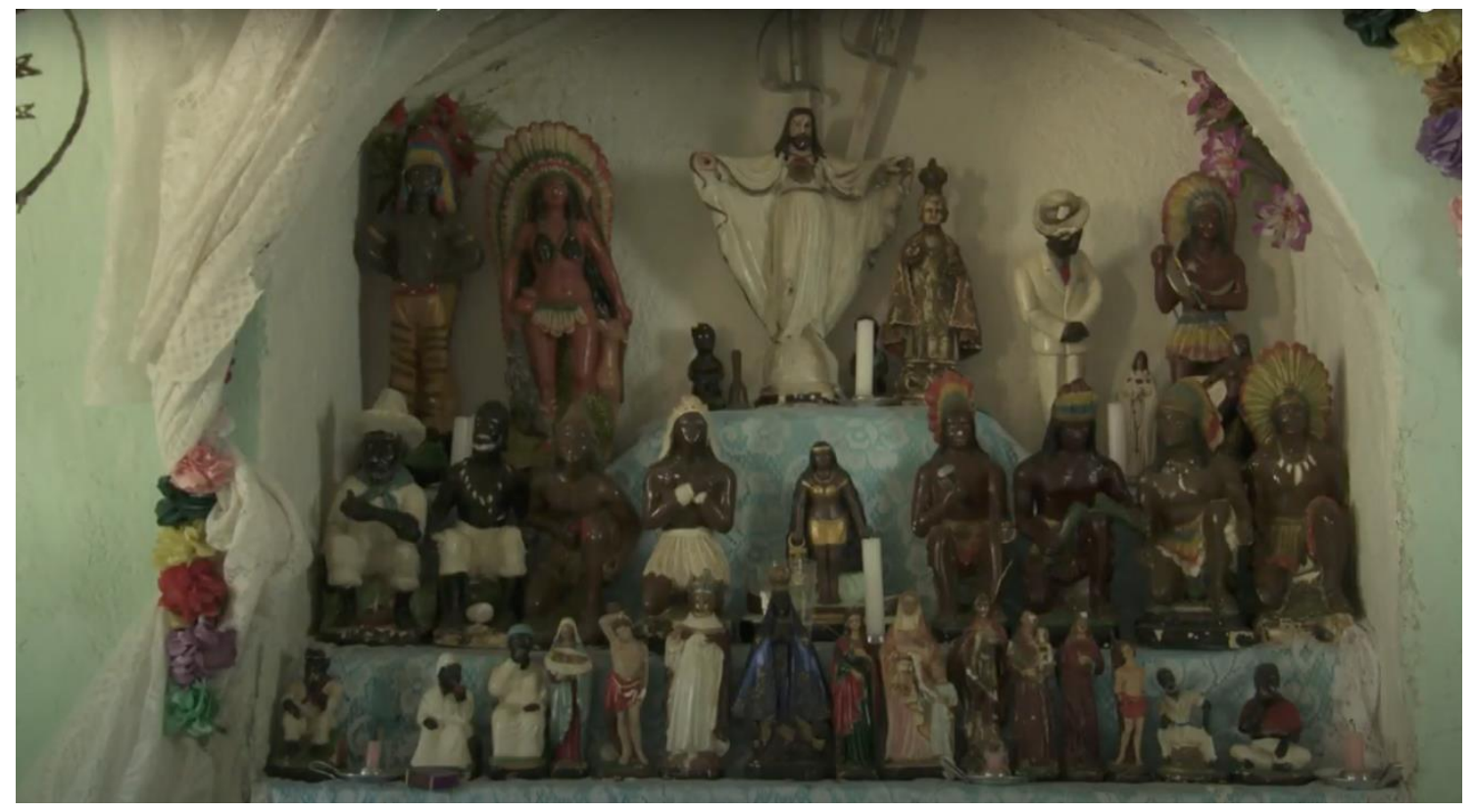

Em off, outro ponto: vai-se assim esboçando uma linha narrativa que se guia pelos cantos da Umbanda:
Ele é um caboclo bruto
lá no fundo do grotão.
Tira a pemba,
risca o ponto,
vem salvar nossos irmãos.
Tira a pemba,
risca o ponto,
vem salvar nossa nação.

No filme, o ponto entoado junto às imagens - a última delas, a do caboclo Pena Branca, braços cruzados sobre o peito, filmado em plano fechado - sugere a preparação de uma tarefa, que exige proteção. O travelling em um carro, em seguida, nos leva a uma viagem até a Fazenda Liberdade, e quando o carro para diante da porteira, é a caveira de boi que nos olha.

Maria Luiza caminha pela fazenda, primeiro à distância, depois acompanhada de perto pelo zoom (o que produz a dissociação entre o som do entorno da câmera e o caminhar 
silencioso da personagem). Ela observa tudo com atenção - o mato alto - como se reencontrasse o lugar, há tempos não visitado.

Na conversa com a amiga que a acompanha, Lena, sabemos que a fazenda foi construída com o suor e o sofrimento dos negros do quilombo: batizada de Liberdade pela Princesa Isabel, a fazenda continuou recebendo e abrigando escravizados, mesmo após a abolição formal. Tomado pelo abandono, o lugar passou a ser amaldiçoado: "nada aqui tem, nada se dá. Era um lugar onde tinha tudo, tinha muita fruta, verduras, uma lagoa com muito peixe... no momento em que botaram a fazenda abaixo, os peixes também se foram, junto com a história desse terrível pedaço de nossas vidas".

Abrupta e ruidosamente, uma carroça, conduzida pelos "novos capatazes", cruza a imagem e, tendo surgido logo depois do testemunho de Maria Luiza sobre a fazenda, ganha ares fantasmagóricos. Como se a virulenta passagem da carroça atualizasse, na coabitação dos tempos, uma cena de outrora.

\section{Quem caminha com as almas caminha devagarinho. \\ É devagar, é devagarinho, quem caminha com as almas nunca se perde no caminho. \\ Criança levanta cedo, com velho vai caminhar, o caminho é muito longe, velho caminha devagar.}

Entoado com a amiga enquanto circulam lentamente pelo espaço, o canto diz da memória do lugar - os pretos velhos e as crianças -, e se endereça também, de modo oblíquo, ao próprio documentário (aos alunos), que devem ir devagar, sem se apressar. Vamos percebendo que a narrativa dos cantos, por meio dos cantos, junto às caminhadas da personagem (aqui tomadas como quatro giras), produz uma espécie de enredamento do filme: como se a câmera, aqueles que com ela visitam a fazenda, estivessem participando de uma tarefa - uma missão, um chamado - sobre a qual não se tem pleno conhecimento, mas que vai se dando a ver aos poucos. O cinema, que muitas vezes se quer soberano em relação ao que filma, vai sendo pouco a pouco conduzido pelos cantos, pelas caminhadas circulares, pelos mistérios e memórias do lugar.

Outro canto, e um corte nos devolve então a imagem do preto velho no congá do Centro Espírita: não se trata apenas de um salto espacial, a passagem de um lugar à outro da fazenda ao terreiro - mas uma passagem temporal, a coabitação, na montagem, de tempos distantes, um a reverberar no outro: o tempo de outrora, com a resistência dos escravizados na fazenda, tal como rememora Maria Luiza, e o tempo de agora, em que a força dos pretos velhos torna-se presente por meio da Umbanda, e é retomada como proteção para a tarefa em curso. Esse corte - que permite avizinhar não apenas espaços 
distintos, mas também tempos distantes - lembra a sugestão, em outro contexto, em torno de uma montagem cósmica (ou cosmológica): nela, o corte seco não apenas expõe o caráter explicitamente construído do filme, acusando o interstício entre as imagens, mas nos sugere também uma continuidade subterrânea que essas distâncias guardam: entre a visita à fazenda no presente do filme e a imagem do preto velho a nos olhar do congá, algo passa, em uma espécie de continuum entre espaços e tempos díspares ${ }^{15}$.

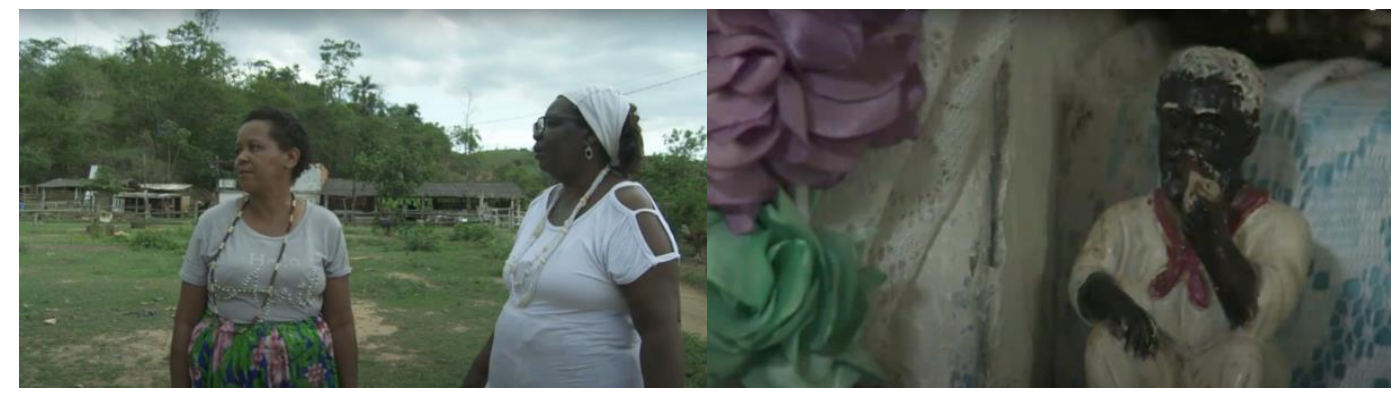

Voltamos à fazenda onde Maria Luiza está com os netos: iniciando um repentino ritual, ela ergue a neta, escolhida por lansã para ser a próxima Mãe Pequena do terreiro. "Eparrei, minha mãe!" Entre o rito e o jogo, Maria Luiza inicia com as crianças uma ciranda "quem não sabe pular corda, não sabe sapatear". Novamente, tempos distintos coabitam a cena conduzida por ela - o tempo atual na fazenda que se altera pelo tempo da infância, sob a regência dos Erês.

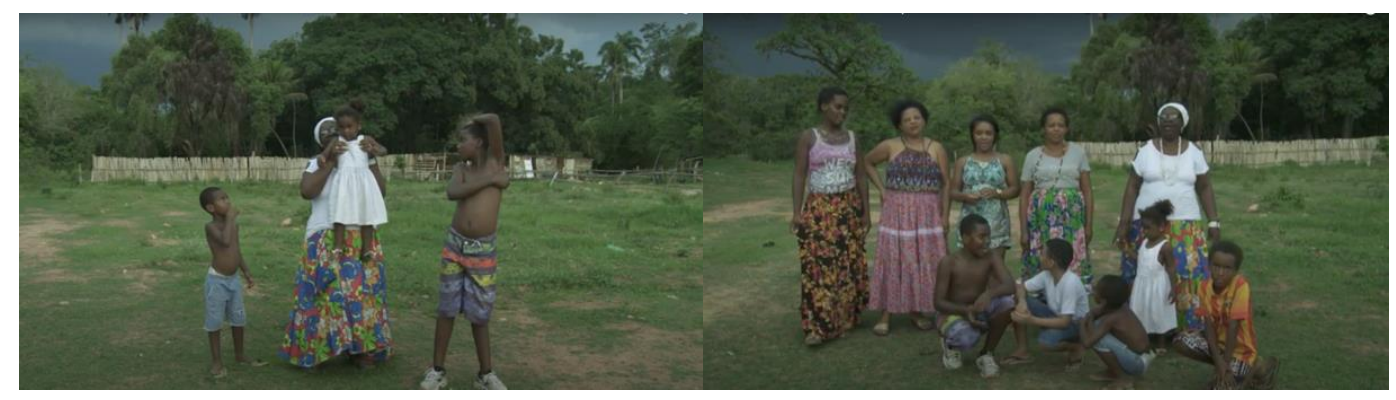

O ritual prossegue - atualizando a experiência do aquilombamento - quando Maria Luiza dirige o retrato com a família e as amigas, diante da mata da fazenda. "Adeus, adeus. Eu já vou embora. Vou pra mata virgem, onde a jurema mora." Nesse momento, algo já se passa

\footnotetext{
${ }^{15}$ Trata-se, como formulou André Brasil, de um corte paradoxal: corte seco, ele não resulta em descontinuidade (já que há algo que passa de um espaço a outro, de um tempo a outro) e, por sua vez, a continuidade apreendida no conjunto não resulta em um todo orgânico, facilmente explicável: "A montagem cósmica permite revelar a continuidade do descontínuo e a descontinuidade do contínuo (que surge, desaparece, adormece, ressurge inesperadamente para se religar ao heterogêneo de onde provém e para onde retorna sem cessar)" (BRASIL, 2018, p. 7).
} 
sutilmente na imagem, que ganha uma quase imperceptível variação meteorológica na luminosidade (ASPAHAN, 2017) ${ }^{16}$.

A transformação se precipita. Os periquitos se alvoroçam. E, em uma última caminhada pelo lugar, o tempo fecha subitamente. No interior mesmo do plano-sequência, sem corte, a câmera enquadra o céu que anuncia a tempestade. Inicia-se a ventania. Aqui, novamente - não mais em uma operação da montagem, mas no interior do plano - o peso da história e o evento cósmico, cosmológico se atravessam. Um novo retrato se faz, agora sob a estridência dos pássaros e a chegada disruptiva do vento. A câmera abre o enquadramento e vemos a paisagem transtornada. As palmeiras pendem, vergam na ventania. "Não tô falando que lansã ia responder?", ouvimos de Maria Luiza. Em sucessivos zooms, a câmera parece desnortear-se com a força da alteração em curso. O som das rajadas de vento, o alvoroço das crianças, que correm de volta. Maria Luiza, por sua vez, mantém alguma calma, como se, no fundo, esperasse pelo acontecimento.

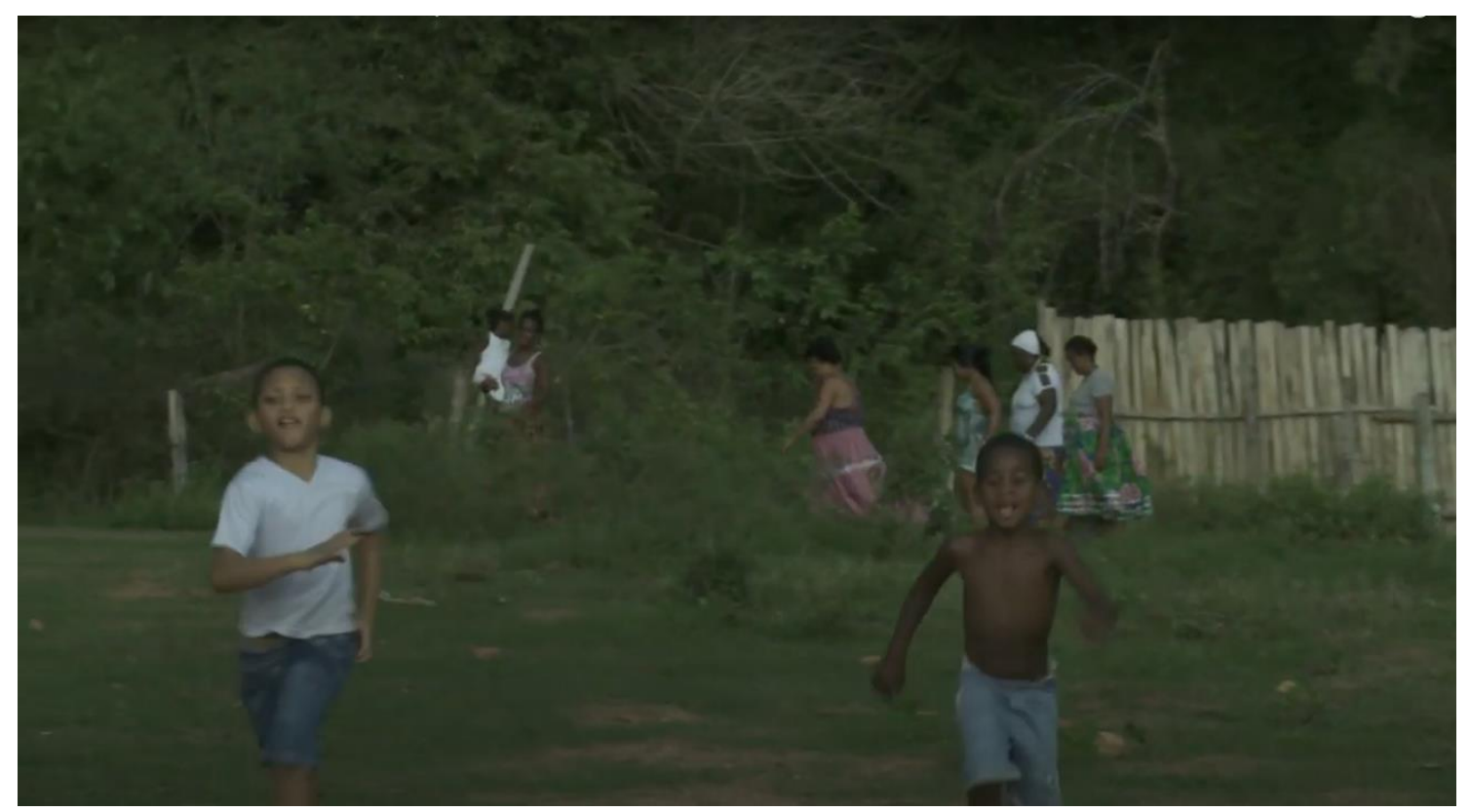

Daí até o fim, o filme será tomado pela força do vento: como se tudo houvesse sido uma preparação para filmar a irresistível ação de sua presença invisível. De novo, o canto é o que conduz a cena e parece dar ciência de como lidar com o acontecimento. "Ventou, mas que ventania. lansã é minha mãe, Santa Bárbara é nossa guia".

\footnotetext{
${ }^{16}$ Esta noção foi utilizada por Pedro Aspahan na análise dos princípios cinematográfico afins à Estética do Serialismo na obra de Straub-Huillet. As variações meteorológicas oferecem ao espectador o acesso a uma manifestação da natureza, vivenciada no momento da filmagem, como uma cintilação da luz pelo movimento das nuvens que encobrem o sol por um instante, ou o movimento das folhas sob o vento, algo da ordem da aleatoriedade do acontecimento natural, em contraste com o rigor serial do enquadramento geométrico do Ponto Estratégico e com tudo aquilo que pode ser controlado pelos realizadores.
} 


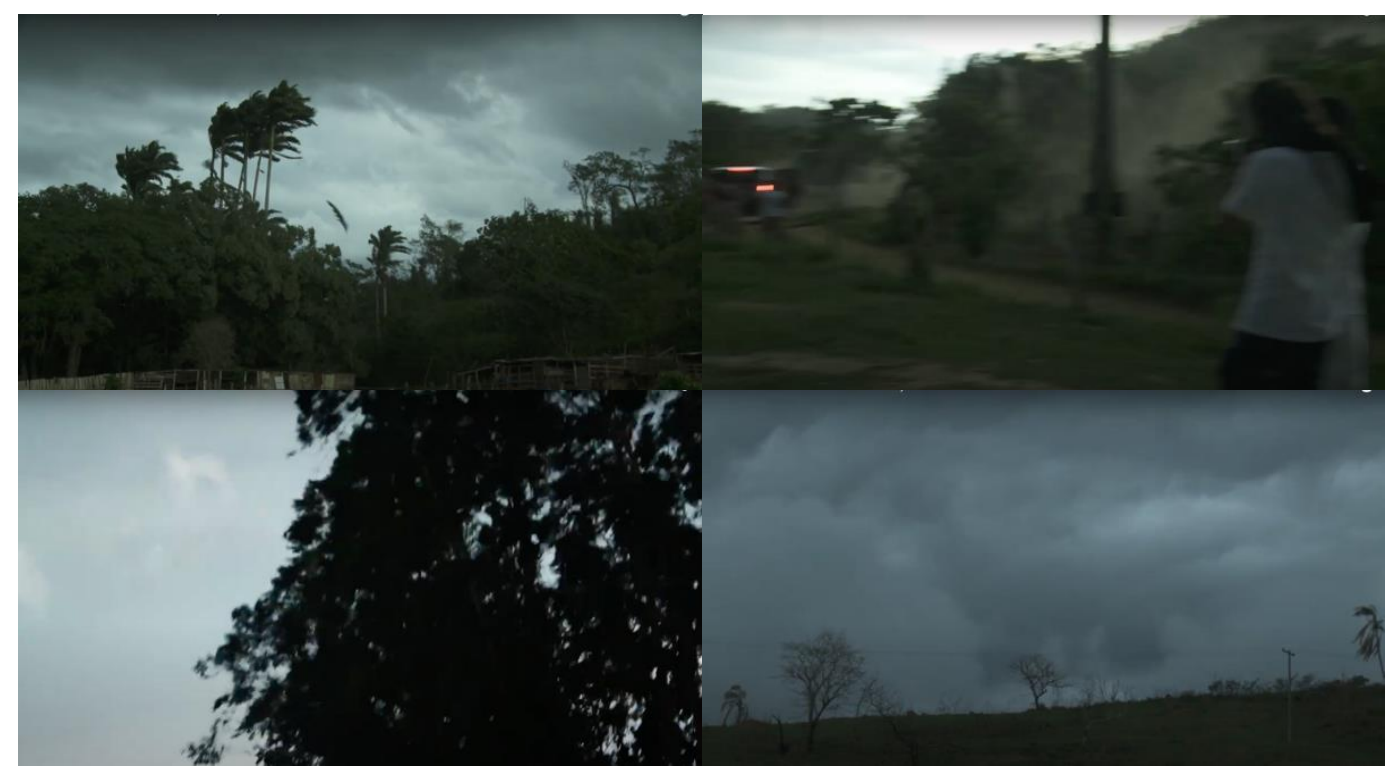

A ventania transtorna a cena, atravessa o enquadramento com sua força que a tudo transforma e transborda. Se o cinema visita o quilombo e a fazenda para apreender (e aprender) um pouco de sua experiência histórica, ele vê o curso de seu aprendizado ser fortemente alterado por forças que ele não domina; ele se vê no interior de uma gira (ou várias), da qual o vento - lansã - é guia.

Que o vento atravesse violentamente as imagens; que as forças vindas do mundo, o mundo natural em aliança com o ritual, tomem para si o curso do filme, é o que afinal constituirá a pedagogia de sua forma e materialidade sensível (esta que se endereça ao espectador e que se relaciona com esta outra pedagogia, a do processo de sua feitura): o vento atravessa as imagens para que as imagens retornem ao mundo, como a cumprir um chamado. Em conjunto, estas constituem pedagogias do vento: por meio do processo de feitura compartilhada entre mestra Maria Luiza e seus parentes em Ubá, os alunos e professores da universidade e por meio da inscrição deste processo na matéria sensível das imagens, elas nos ensinam algo sobre este saber complexo e sofisticado que sobreviveu e resistiu aos processos históricos de colonização e escravização, reelaborando-os por meio dos saberes mágico-animistas. No encontro entre os conhecimentos acadêmicos e os conhecimentos quilombolas, o filme participa circunstancialmente de um processo de transmissão (que, em determinado momento, precisa da presença acontecimental da natureza para se expressar): transmissão entre a mãe de santo do terreiro e a Mãe Pequena designada por lansã; entre adultos, jovens e crianças; entre a comunidade do quilombo e o grupo da universidade; transmissão dos saberes dos cantos e dos saberes dos Orixás e encantados.

Quando, ao final, após os créditos, vemos a foto antiga da Fazenda Liberdade, o filme ressalta seu valor de testemunho e documento: ele não atesta uma história perdida no 
passado, mas sua elaboração que continua a ser feita no presente e para a qual a universidade e o cinema são chamados agora a compor.

Como procuramos demonstrar, a tarefa do cinema documentário é aqui fortemente deslocada: não se trata estritamente de viajar para filmar uma realidade outra, distante, mas de compor com pedagogias que ultrapassam o filme; atender a um chamado que se anunciava, já naquele encontro em uma cantina na universidade e, depois, de modo mais contundente, na primeira aula de Maria Luiza na UFMG. Aqui, buscamos descrever e narrar esses processos (nada lineares) que tornam o filme uma experiência multifacetada, para além de sua formalização: a inscrição nas imagens deixa traços de um trabalho que vem de longe e que o vento anuncia, transporta, transtorna, ensina e prossegue.

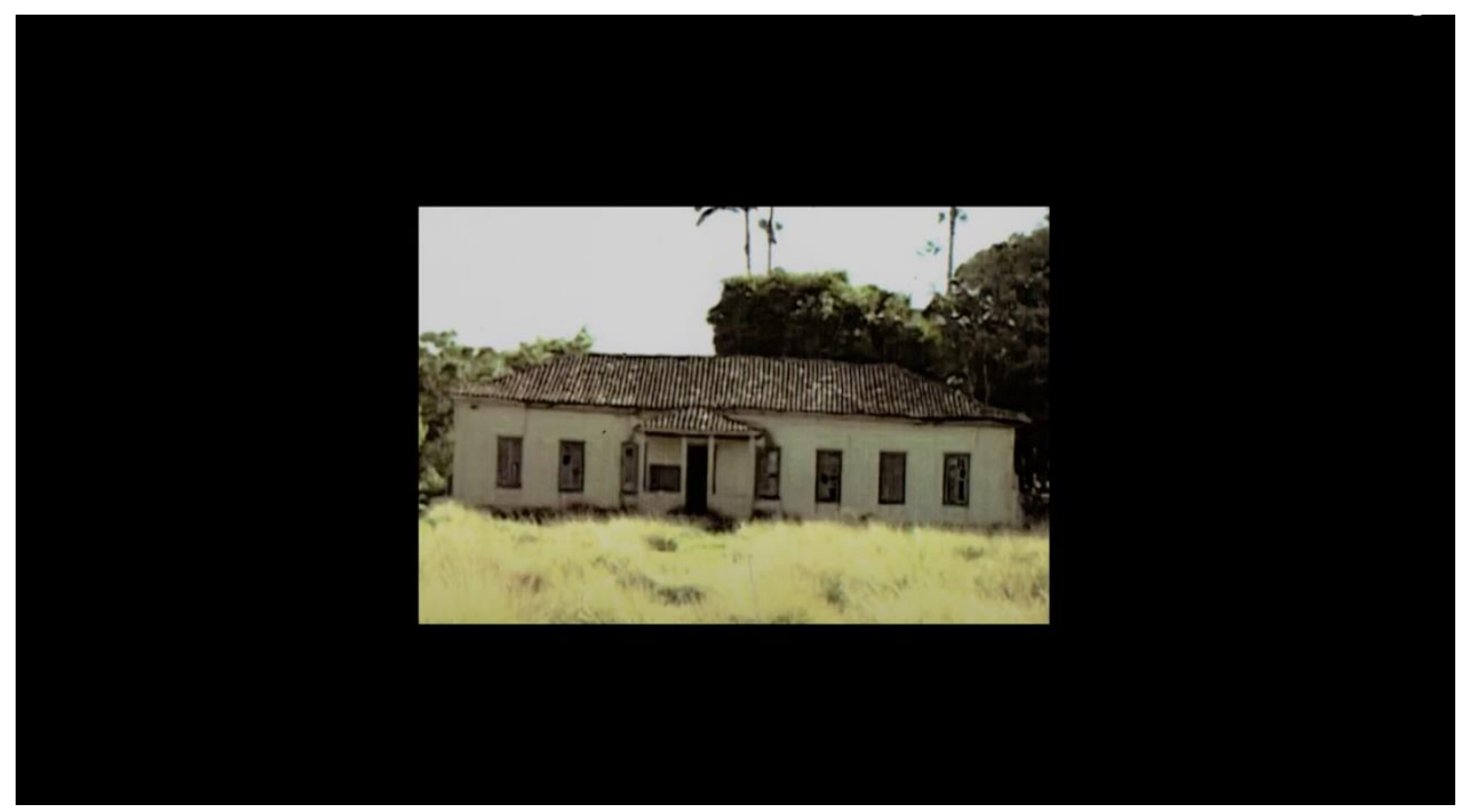

\section{REFERÊNCIAS}

ASPAHAN, Pedro. Composição Musical e Pensamento Cinematográfico: A Estética do Serialismo no Cinema de Straub-Huillet. Belo Horizonte: UFMG, 2017 (orientação: César Guimarães), 325 f. Disponível em: https://repositorio.ufmg.br/handle/1843/BUOS-AS9FQU. Acesso em 22/07/2020.

BRASIL, André. "Tempo é o vento, vento é tempo": montagem cósmica em Abá. In: Catálogo do forumdoc.bh 2018. Belo Horizonte: Filmes de Quintal, 2018.

CASIMIRA, Isabel; TORRES, Júnia. A Rainha Nzinga chegou, 2019.

COMOLLI, Jean-Louis. Ver e poder. A inocência perdida. Cinema, televisão, ficção, documentário. Belo Horizonte: Editora UFMG, 2008.

GUIMARÃES, César. Filmar os terreiros, ontem e hoje. Perspectivas em Ciência da Informação, v.24, número especial, p. 23-36, jan./mar. 2019, p. 26. Disponível em: http://portaldeperiodicos.eci.ufmg.br/index.php/pci/article/view/3891. Acesso em 17/07/2020. 
GODARD, Jean-Luc. Histoire(s) du cinema, 1988-1998.

IVENS, Joris; LORIDA, Marceline. A história do vento. 1988.

NINEY, François. Le documentaire et ses faux-semblants. Paris: Klincksieck, 2009.

SANTOS, Antônio Bispo dos. Colonização, quilombos. Modos e significações. Brasília: INCTI/UnB, 2015. UFMG, Programa de Formação Transversal em Saberes Tradicionais da UFMG. 0 Boi de Oliveira. 2018.

Recebido em 12 de agosto de 2020. Aprovado em 23 de fevereiro de 2021. 